\title{
Infestation of Asterias rubens (Echinodermata) by the ciliate Orchitophrya stellarum: effect on gonads and host reaction
}

\author{
C. Bouland*, M. Jangoux \\ Laboratoire de Biologie marine (CP 160), Université Libre de Bruxelles, 50, av. F. D. Roosevelt, B-1050 Bruxelles, Belgium
}

\begin{abstract}
Infestation of male Asterias rubens L. by the ciliate Orchitophrya stellarum Cépède results in testis regression and asteroid castration. Ciliates disorganize the germinal epithelium and phagocytise germ cells. Infested testes are massively invaded by the host's phagocytic cells which also phagocytize germ cells. It is suggested that the phagocytic cells do not react against invading ciliates but against host. tissues damaged by the parasites.
\end{abstract}

So far, Orchitophrya stellarum is the only ciliate demonstrated to act as a parasite of echinoderms. Originally described by Cépède (1907), who considered it to be an Astomatous ciliate, $O$. stellarum was recently proven to be a Scuticociliate (Bouland et al. 1987). The parasite has been reported several times from the gonads - mostly testes - of asteriid asteroids (for review see Jangoux 1987). According to Cépède (1907, 1910), $O$. stellarum causes the degeneration of the germinal tissue and produces either total or partial castration of its host, depending on the number of infested testes. Vevers (1951) reported that the nutrient medium in which the ciliates are living is that of ripening germ cells. Lowe (1978) suggested that germinal cells are phagocytized by the ciliates. The purpose of the present note is to characterize, from microscopic studies, the effect of $O$. stellarum on the host's testes and the way Asterias rubens counteracts invading ciliates.

Methods. Asterias rubens was collected in April 1986 in the Delta area (Zeeland, The Netherlands), by SCUBA diving at $10 \mathrm{~m}$ depth in the Grevelingen Sea, and by dredging at $17 \mathrm{~m}$ in the Oosterschelde. For light microscopy, infested gonads were fixed in Bouin's fluid, embedded in paraplast and cut into $5 \mu \mathrm{m}$ thick sections. Masson's trichrome, oxidized Alcian blue (permanganic oxidation) followed by Groat's hematox-

\footnotetext{
- Present address: Department of Biology, University of Victoria, Victoria, B. C., Canada V8W 2 Y2
}

ylin and phloxine, and the Alcian blue pH 2.6-Periodic Acid Schiff method were used as routine staining procedures (Ganther \& Jollès 1969-1970). For transmission electron microscopy (TEM), gonad fragments were fixed in $3.5 \%$ glutaraldehyde in cacodylate buffer 10.4 $\mathrm{M}, \mathrm{pH} 7,4, \mathrm{NaCl} 7 \%$ ) for 1 h at $4{ }^{\circ} \mathrm{C}$. Pieces were rinsed in cacodylate buffer and postfixed for $1 \mathrm{~h}$ in $1 \%$ osmium tetroxide in the same buffer. Pieces were rinsed again in the same buffer, dehydrated in graded ethanol, embedded in Spurr medium and cut using a LKB V ultramicrotome. Ultra-thin sections were contrasted with uranyl acetate and lead citrate, and examined in a Phillips EM 300 transmission electron microscope. For scanning electron microscopy (SEM), gonadal fragments were fixed using the technique already described for TEM observations. Pieces were then dehydrated in graded ethanol, dried by critical point method (using $\mathrm{CO}_{2}$ as transition fluid), mounted on aluminium stubs, coated with gold and observed with a ISI DS 130 scanning electron microscope

Results and Discussion. None of the 60 asteroids (33 males, 27 females) collected in the Grevelingen Sea was infested, while 5 of the 67 asteroids (35 males, 32 females) from the Oosterschelde were. Only male

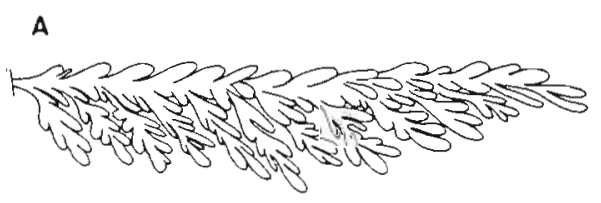

B

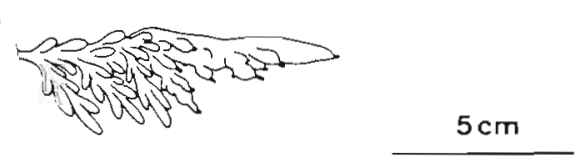

Fig. 1. General aspect of healthy (A) and infested (B) testes 

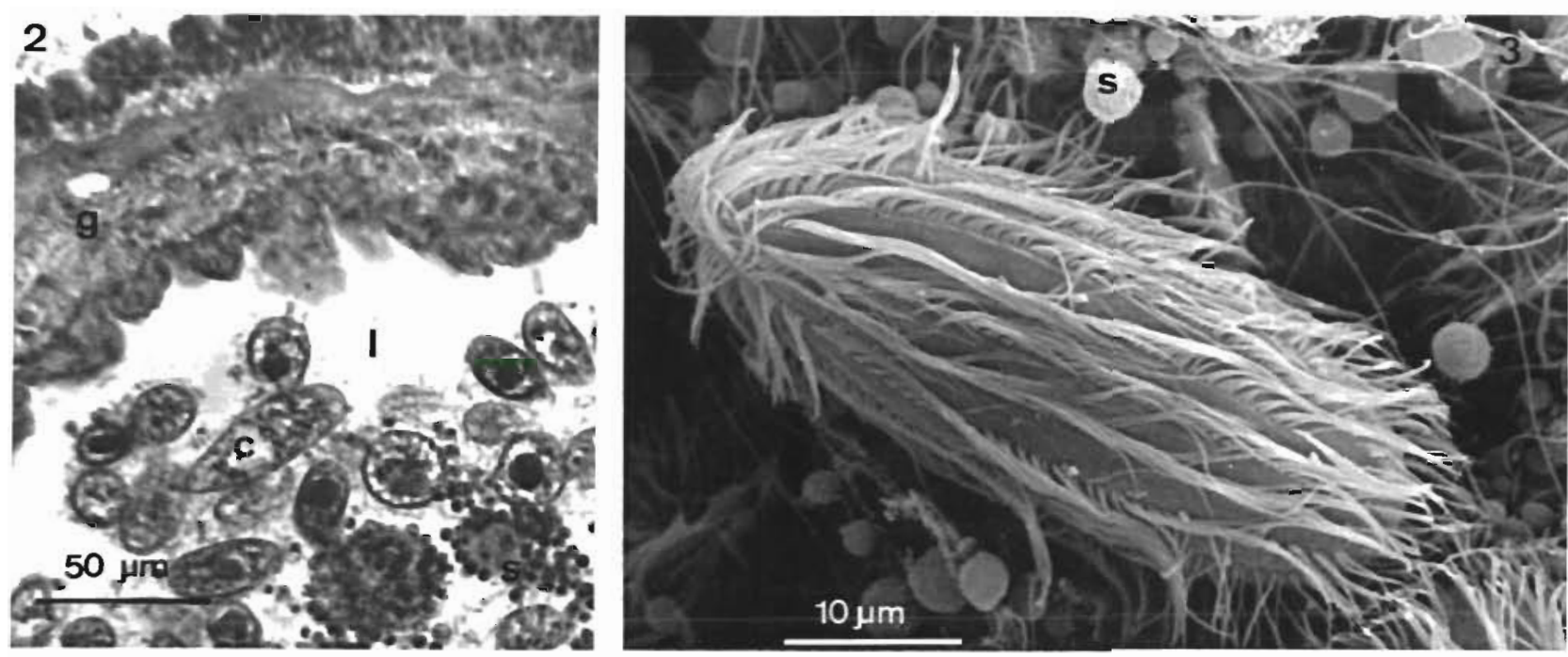

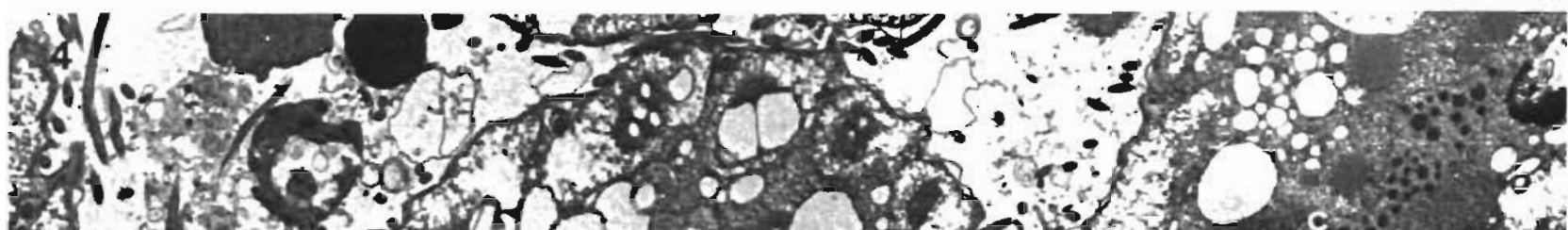

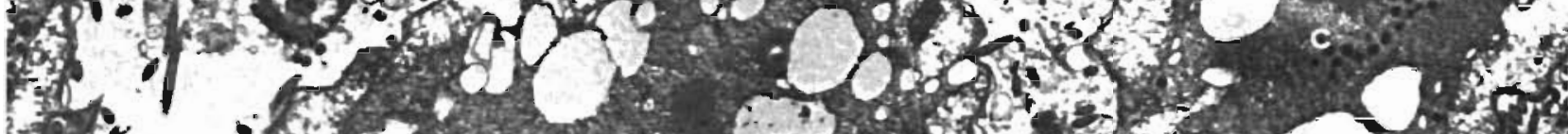

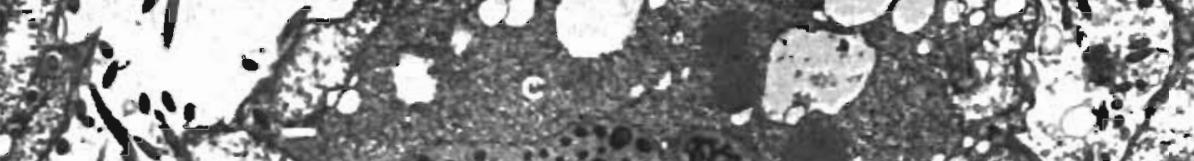
1. 5 .

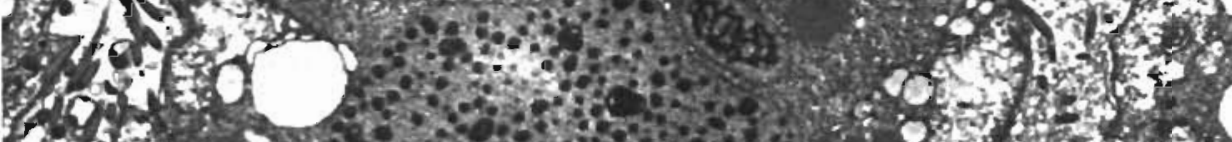

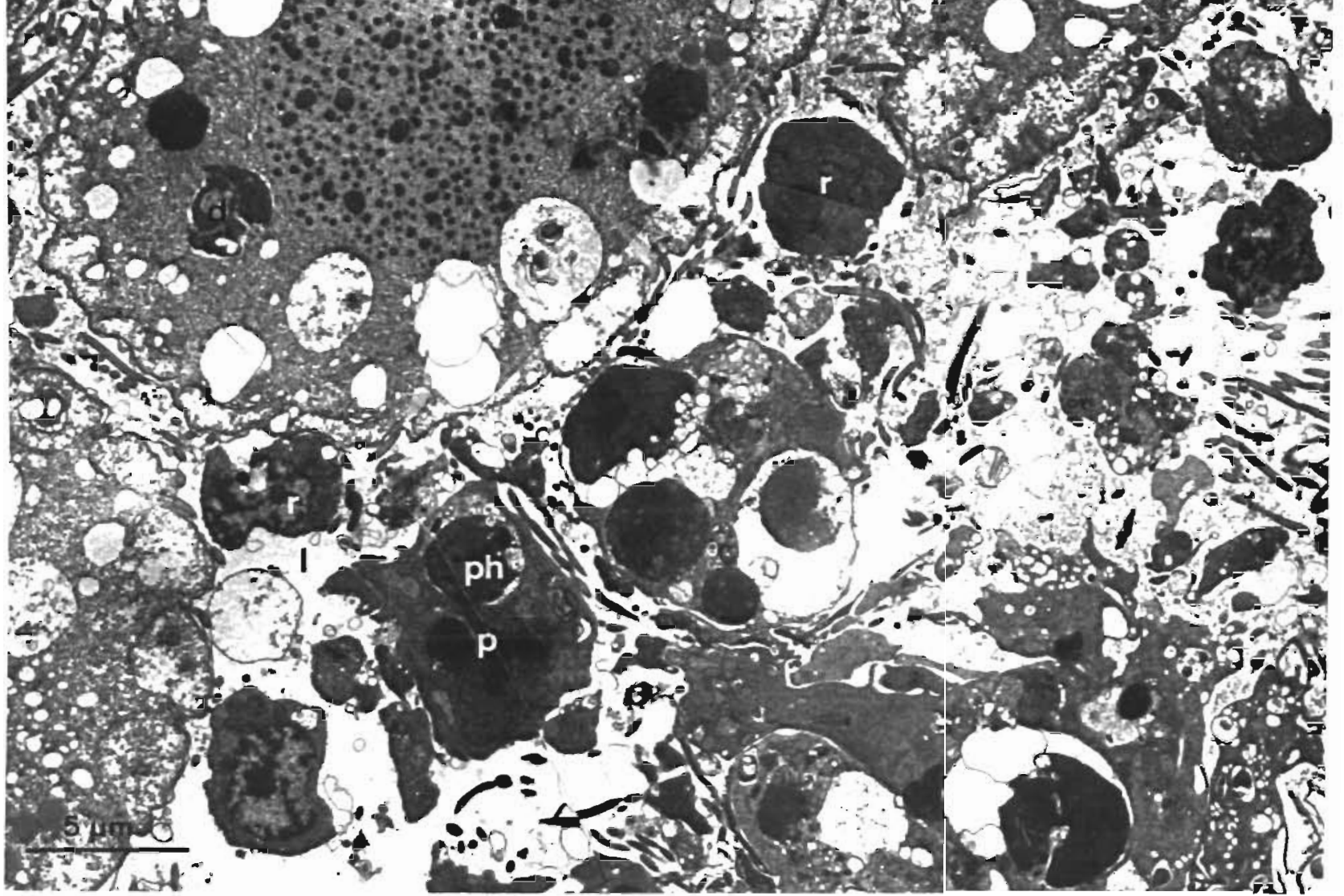




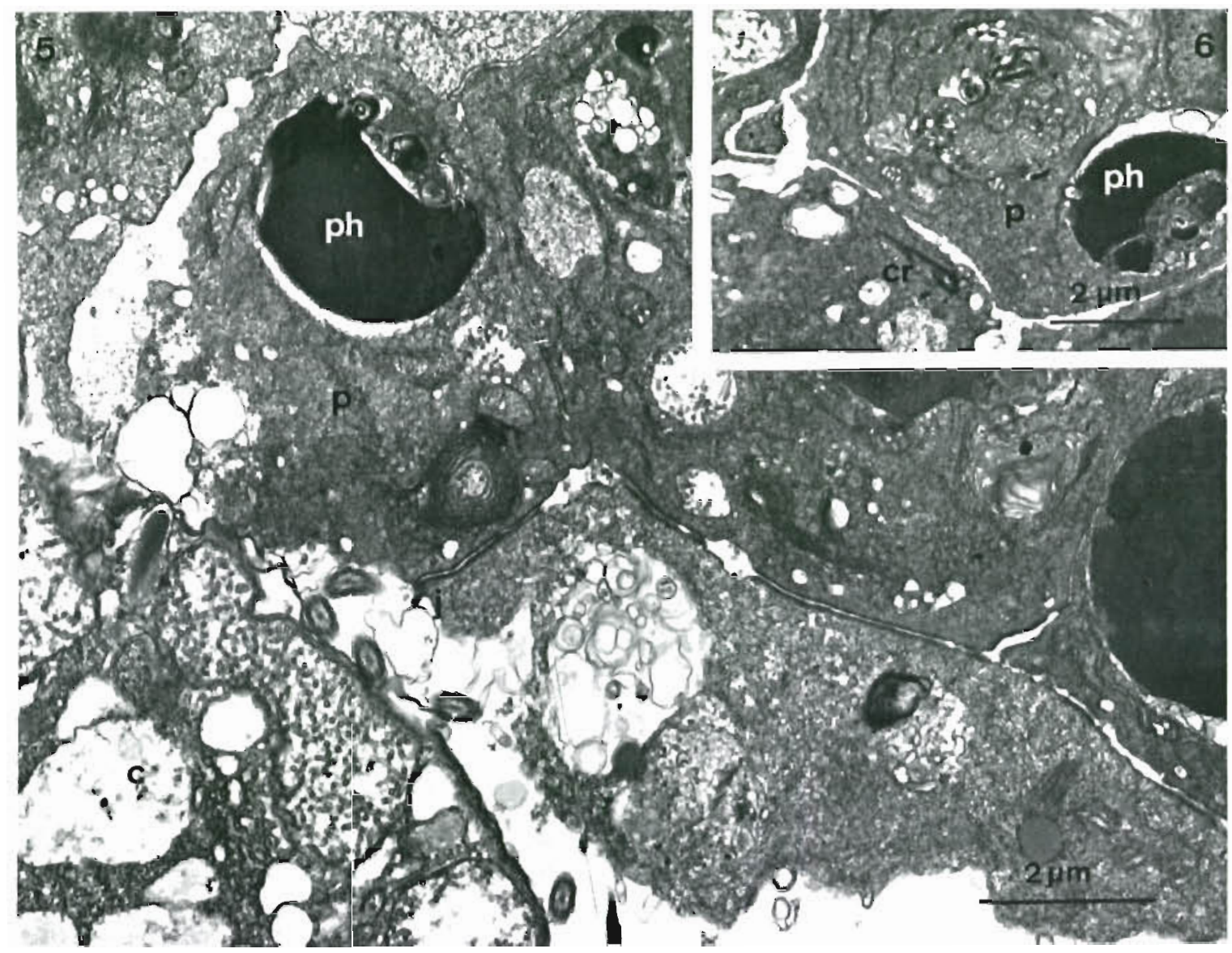

Figs. 5 and 6. Asterias rubens. Fiq. 5. Epithelialization of phagocytic cells along the inner surface of the testis wall. Fiq. 6 Occurrence of ciliary root and centriole in phagocytic cells. c: ciliate; cr: ciliary root; j: intercellular junction; p: phagocytic cell; ph: phagosome

asteroids were infested. Depending on the individual, the number of affected testes per asteroid varied from 2 to 4 . In most cases, infestations involved only the testis' distal half or distal third, which was violet or blueish in color (instead of cream) and markedly reduced in size (Fig. 1). Infestation of whole testis was observed in 3 cases only. Infested testes were either at pre-mature or mature stages (see Jangoux \& Vloeberg 1973 for description and illustration of gonadal stages). Vevers (1951) indicated that parasitized testes never showed mobile sperms even when the infection was relatively light. We observed, however, mobile spermatozoa in the healthy part of partly affected testes. (Whether or not these sperm cells could be spawned is not known.) Parasitism of Asterias spp. by Ochitophrya stellarum has been reported from both sides of the North Atlantic. From the data compiled by Jangoux (1987), it appears that the parasite mostly affects male asteroids. How- ever infestation of female asteroids was reported in 2 cases in Asterias populations from the NW Atlantic (Burrows 1936, Smith 1936).

The lumen of infested testes was packed with cells of various types (Figs. 2 to 4 ). These testes always showed a highly disorganized germinal epithelium. Spermatogonia and spermatozoa were distributed all over the lumen, interspersed with numerous ciliates and host phagocytic cells. Both ciliates and phagocytic cells actively phagocytized germinal cells and contained large phagosomes, some of which were filled with germ cell remains (Figs. 4,6). The fine structure of the ciliates has been described by Bouland et al. (1987). Phagocytic cells typically had a kidney-shaped nucleus and enlarged phagosomes. They lacked a cilium but had a well-developed pericentriolar complex consisting of 2 centrioles and a striated ciliary root (Fig. 6), usually associated with 2 Golgi systems and some mi-

Figs. 2 to 4. Orchitophrya stellarum. Fig. 2. Histological section through an infested testis of Asterias rubens. Fig. 3. SEM-view of $O$. stellarum in a ripe testis of $A$. rubens. Fig. 4. TEM-section through an infested testis of $A$. rubens showing both ciliates and host's phagocytic cells. c: ciliate; d: digestive vacuole; g: gonadal wall; l: lumen; p: phagocytic cell; ph: phagosome; r: remains of spermatozoa; s: spermatozoa 
crotubules. The pericentriolar complex closely ressembled that described by Maes \& Jangoux (1983) in the coelomocytes of Asterias rubens. Depending on the observed testis, the inner surface of the gonadal wall was limited either by the basal lamina of the former germial epithelium or by a layer of phagocytic cells closely applied against that lamina. These phagocytic cells may develop intercellular junctions (Fig. 5), thus forming a new intragonadal epithelium of strict somatic origin.

Phagocytic cells are normally present in healthy asteroid gonads (Cognetti \& Delavault 1962). They are involved, for instance, in the postspawning lysis of residual gametes (Walker 1980) and in the winter lysis of oocytes in some asteroid species (Ferrand 1983). Striking ultrastructural similarities occur between intragonadal phagocytic cells and those observed in other systems such as the hemal and coelomic systems (Walker 1980, Maes \& Jangoux 1983, Bouland et al. 1985). This could mean that a kind of diffuse phagocytic tissue occurs throughout the asteroid body - a tissue that can be mobilized under stress conditions such as infestation or injury. While there is no direct evidence of the origin of that particular tissue, there are some indications that it could originate from the asteroid mesothelial (peritoneal) lining (e.g. Vanden Bossche \& Jangoux 1976)

Orchitophrya stellarum disorganizes the germinal epithelium (disruption of spermatic columns) and phagocytizes germ cells, and ciliate infestation obviously results in testis regression and partial castration. Yet, germ cells are also phagocytized by host phagocytic cells. Surprisingly the latter never attack ciliates, which always appear perfectly heathy (Fig. 3). The invasion of infested testes by phagocytic cells is very similar to that which takes place naturally after spawning (Walker 1980). This suggests that phagocytic cell mobilisation may be basically induced by the disorganization of the germinal epithelium, and that phagocytic cell reaction in infested testis is not directed against invading ciliates but against the damaged host tissues.

Acknowledgements. We thank 2 anonymous referees for useful comments; Dr G. Doornbos and the crew of the vessel 'Luctor' (Delta Institute, Netherlands) for dredging facilities;
E. Bricourt and J. Harray for technical assistance. Work supported by an ECC Stimulation Action (ref. ST2J-0105-1-B).

\section{LITERATURE CITED}

Bouland, C., De Puytorac, P., Bricourt, E. (1987). Orchitophrya stellarum, cilié prétendu astome, est un scuticocilié. Ann. Sci. nat. Zool. (13) 8: 249-257

Bouland, C., Yourassowsky, C., Jangoux, M. (1985). Fine structure and presumed functions of the gastric hemal tufts of the asteroid, Asterias rubens L. In: Keegan, B.F., O'Connor, B. D. S. (eds.) Echinodermata. Balkema, Rotterdam, p. 481-488

Burrows, R. B. (1936). Further observations on parasitism in the starfish. Science 84: 329

Cépède, C. (1907). La castration parasitaire des étoiles de mer máles par un nouvel infusoire astome: Orchitophrya stellarum n.g., n.sp. C. r. Acad. Sci. Paris 145: 105-1306

Cépède, C. (1910). Recherches sur les infusoires astomes: anatomie, biologie, éthologie parasitaire et systématique. Archs Zool. exp. gén. (5) 3: 341-609

Cognetti, G., Delavault, R. (1962). La sexualité des astérides. Cah. Biol. mar. 3: 157-182

Ferrand, J. G. (1983). Ultrastructural analysis of oocyte lysis and phagocytic activity in gonads of Asterina gibbosa P. (Echinodermata, Asteroidea). Int. J. Invert. Reprod. 6: $21-29$

Ganther, P. Jollès, G. (1969-1970). Histologie normale et pathologique (2 vols). Gauthier-Villars, Paris

Jangoux, M. (1987). Diseases of Echinodermata. I. Agents microorganisms and protistans. Dis. aquat. Org. 2: 147-162

Jangoux, M., Vloeberg, M. (1973). Contribution à l'étude du cycle annuel de reproduction d'une population d'Asterias rubens L. (Echinodermata, Asteroidea) du littoral belge. Neth. J. Sea Res. 6: 389-408

Lowe, E. F. (1978). Relationship between biochemical and caloric composition and reproductive cycle in Asterias vulgaris (Echinodermata, Asteroidea) from the Gulf of Maine. Ph. D. diss., Univ, Maine, Orono

Maes, P., Jangoux M. (1983). Occurrence of a well-developed pericentriolar complex within the cytoplasm of asteroid coelomocytes (Echinodermata). Devel. comp. Immunol. 7 : 691-694

Smith, G. F. (1936). A gonad parasite of the starfish. Science 84: 157

Vanden Bossche, J. P., Jangoux, M. (1976). Epithelial origin of starfish coelomocytes. Nature, Lond. 261: 227-228

Vevers, H. G. (1951). The biology of Asterias rubens L. 2 Parasitization of the gonads by the ciliate Orchitophrya stellarum Cépède. J. mar. Biol. Ass. U. K. 29: 619-624

Walker, C. W. (1980). Spermatogenic columns, somatic cells, and the microenvironments of germinal cells in the testis of asteroids. J. Morphol. 166: 81-107 